Наталія Руднік

Тетяна Шевчук

Тетяна Поручинська

\title{
Роль цитогенетичної діагностики у виявленні хромосомної патології та поліморфізмів хромосом у постнатальному періоді розвитку у Волинській області
}

Підтверджено важливість класичного цитогенетичного методу в питаннях діагностики хромосомної патології, медико-генетичного консультування та прогнозування потомства у Волинській області. Для проведення цитогенетичного дослідження застосовували: метод культивування лімфоцитів периферійної крові людини в постнатальному періоді розвитку, приготування препаратів метафазних хромосом людини, визначення каріотипу методом аналізу метафазних пластинок хромосом та виявлення хромосомних аномалій і поліморфізмів хромосом. Кількість обстежуваних протягом 2012-2014 рр. у Волинській області всіх вікових категорій, які направлялися на обстеження, становила 559 осіб жіночої та чоловічої статі. У І групи осіб визначено нормальний каріотип; у II групи виявлено поліморфізми хромосом 1, 9, 16, 13-15, 21, 22, Ү; у III групи виявлено хромосомні аномалії та підтверджено діагнози синдромів Дауна, Клайнфельтера, Шеришевського-Тернера, Едвардса, Вольфа-Гіршхорна, дисомії за Ү хромосомою, синдрома ХХ у хлопчика, синдрома ХY у дівчинки та ін.

Ключові слова: класичний цитогенетичний метод, хромосомні аномалії, каріотип, метафазні пластинки, синдром, поліморфізм хромосом.

Постановка наукової проблеми та ії значення. У наш час у великій групі спадкових захворювань генетичного походження особливе місце належить хромосомній патології як одній 3 найдраматичніших медичних і соціальних проблем, за якою стоять і репродуктивні втрати, й порушення психофізичного, соматичного, ендокринного стану, і психосоціальні конфлікти. Хромосомні хвороби (хромосомні синдроми) - це група вроджених спадкових захворювань, спричинених кількісними або структурними аномаліями хромосом, які видимі у світловому мікроскопі та характеризуються множинними вродженими вадами розвитку [6]. Хромосомна патологія супроводжується дисбалансом хромосомного матеріалу та проявляється специфічними фенотиповими порушеннями. Порушення нормального хромосомного балансу неминуче призводить до розладів розвитку організму. Оскільки патогенез хромосомної хвороби розгортається у внутрішньоутробному періоді та пов'язаний із порушеннями в генетичній програмі розвитку на його ранньому етапі, це спричиняє множинні вади розвитку: черепно-лицьові дизморфії, аномалії скелета, вади серцево-судинної, нервової, сечостатевої систем, шлунково-кишкового тракту, різноманітні відхилення в біохімічному, імунологічному статусі, а також затримки загального фізичного і психомоторного розвитку. Ступінь відхилень у розвитку організму залежить передусім від вираженості хромосомного дисбалансу. Так, повні трисомії або моносомії переносяться важче, ніж часткові, дисбаланс за малими хромосоми трапляється частіше, ніж за великими. Повних моносомій за малими хромосомами не знайдено, дуже рідкісні вони й серед спонтанних абортів. Особливий інтерес викликають збалансовані зміни хромосом, у яких $€$ весь набір генів, проте розміщення їх у межах однієї або декількох хромосом порушене. Носії таких перебудов часто фенотипово нормальні, але для їх нащадків виникає ризик мати незбалансований каріотип [4].

Найбільш поширені в постнатальний період розвитку анеуплоїдії за хромосомами $13,18,21, \mathrm{X}$, Y. У 10 із 1000 новонароджених дітей: $25 \%$ дітей із розумовою відсталістю, $12 \%$ дітей із затримкою психомоторного розвитку - спостерігаються хромосомні зміни. Клінічна картина одних і тих самиххромосомних хвороб дуже варіює. Зміни в системі аутосом викликають більш тяжку клінічну картину, ніж аномалії за статевими хромосомами, які, очевидно, несуть менше генетичної інформації. Мозаїчні форми хромосомних хвороб мають стертий спектр фенотипових проявів, що пояснює наявність клона клітин із нормальною кількістю хромосом. Діагностика таких форм затруднена. Різні методи цитогенетичної діагностики дають змогу виявити структурні аномалії хромосом. Дія мутагенів навколишнього середовища (іонізуючої радіації, хімічних речовин, вірусів) спричиняє утворення хромосомних і хроматичних розривів, пробілів, обмінів у соматичних клітинах, що не викли-

(C) Руднік Н., Шевчук Т., Поручинська Т., 2015 
кають конкретної патології. Однак порушення генного балансу в статевих клітинах є небезпечним для майбутнього покоління [3].

Діагностика хромосомних хвороб - складний і трудомісткий процес, в основі якого лежать клініко-генеалогічний аналіз, соматогенетичне дослідження із синдромологічним аналізом та цитогенетичне дослідження. Цитогенетичний метод діагностики дає нам змогу робити висновок про каріотип хворого - кількість і структуру хромосом, тому досить актуальний у Волинській області.

Аналіз досліджень цієї проблеми. Хромосоми людини зазнають впливу чинників навколишнього середовища і надзвичайно чутливі до дії мутагенних чинників - радіації та хімічних речовин. У разі впливу таких чинників виникають порушення в соматичних або статевих клітинах. Через цитогенетичні порушення в соматичних клітинах страждає життєдіяльність усього організму. У разі впливу зазначених чинників на статеві клітини порушення хромосом проявляються в наступних поколіннях. Мутації хромосом у статевих клітинах призводять до утворення неповних аномальних гамет, у разі запліднення яких уможливлюється загибель зигот, ембріонів, народження дітей із хромосомними хворобами, для яких характерний певний фенотип. Мутації хромосом у соматичних клітинах призводять до неспецифічних хромосомних аномалій у вигляді хромосомних або хроматичних пробілів, розривів, обмінів у каріотипі, що не проявляються певним фенотипом, характерним для окремого хромосомного синдрому. Із геномних мутацій у людини трапляються тільки трисомії за аутосомами, полісомії за статевими хромосомами, моносомії лише за X-хромосомою [2].

3 цілком зрозумілих причин ніяких ефективних методів лікування хромосомних хвороб поки що не винайдено. Глибокі порушення метаболізму і життєздатності кожної клітини не дають змоги уявити, навіть теоретично, будь-яких раціональних підходів до терапії хромосомних хвороб. Ситуація ускладнюється ще й тим, що патологічний геном, який формується під час запліднення і на перших стадіях дроблення, так спотворює програму індивідуального розвитку, що ії корекція, навіть у плода $\mathrm{i}$, тим більше, після народження не дасть позитивних результатів. Великий сумнів викликає думка деяких вітчизняних учених про перспективність терапії хромосомних хвороб методом трансплантації стовбурових клітин. Окремі (офіційно не підтверджені) спроби «лікування» дітей із хворобою Дауна методом трансплантації ембріональних клітин, які проводилися в деяких вітчизняних центрах, наскільки нам відомо, не дали позитивних результатів. Звичайно, створення таких штучних химер, що несуть поряд 3 анеуплоїдними клітинами і клітини 3 нормальним диплоїдним каріотипом, теоретично може сприяти послабленню симптомів, зумовлених патологічним генотипом. Однак трансплантовані клітини ніколи не замінять уже наявні «хворі» клітини. На сьогодні немає ніяких даних про існування на хромосомі 21 центру інактивації всієї хромосоми, подібного до центру Xic на X-хромосомі. Таким чином, не існує реальних підходів до лікування хромосомних хвороб, особливо найбільш поширеної хвороби Дауна. Прогресу у цій галузі можна досягнути лише за рахунок удосконалення методів симптоматичної лікарської терапії, а також через подальше покращення методів соціальної адаптації таких хворих [1].

Мета нашого дослідження - проаналізувати метафазні пластинки хромосом, отримані методом культивування; виявити хромосомні аномалії та поліморфізми у хромосомах людей, які направляються на обстеження; визначити їх каріотипи та вивчити структуру хромосомної патології у волинській популяції для розробки адекватних заходів профілактики, лікування та соціальної адаптації хворих.

Методика та контингент дослідження. Цитогенетичні дослідження здійснювали в лабораторії медичної генетики, імунології, ендокринології та генетичної біохімії ВОДТМО. У процесі роботи використовували методику культивування лімфоцитів периферійної крові людини in vitro в постнатальному періоді її розвитку, застосовували технологію приготування хромосомних препаратів та диференційні методи забарвлення хромосом: GTG-метод (фарбуються G-сегменти хромосом при обробці трипсином із використанням барвника Гімза) та CBG (фарбуються С-сегменти хромосом при обробці гідроокисом барію із використанням барвника Гімза) [10]. Аналізували метафазні пластинки хромосом (не менше 20 для кожного обстежуваного) методом світлової мікроскопії [10], за допомогою комп'ютерної програми каріотипування Cytovision iз використанням мікроскопа OLYMPUS BX41, набором об'єктивів $\times 10,20,40,100$, відеокамери OLYMPUS (JAPAN), монітора, принтера. Для кожної пластинки, яку брали для аналізу, записували ноніуси (X- та Y-координати) в цитогенетичному протоколі та проводили підрахунок і якісний аналіз хромосом у пластинці, вносячи дані в цитогенетичний протокол. У кінці аналізу препаратів робили висновок щодо каріотипу обстежуваного [9]. За період від 2012-го до 2014 р. обстежено 559 осіб чоловічої та жіночої статі різних вікових категорій, які проживають у Волинській області. За результатами каріотипу їх по- 
ділили на три групи: I - група осіб із нормальним каріотипом, II - група осіб із поліморфізмом хромосом, III - група осіб із хромосомними патологіями.

До контингенту, який потребував цитогенетичного аналізу, належали: діти із множинними вадами розвитку та їх батьки; діти із затримкою психомоторного розвитку та їх батьки; діти із затримкою та аномаліями статевого розвитку; особи з клінічними проявами хромосомних синдромів; подружні пари, у яких спостерігається невиношування вагітності та інші репродуктивні втрати; подружні пари 3 обтяженим анамнезом (попередня мертвонароджена дитина, попередня дитина 3 вродженими вадами розвитку чи хромосомною аномалією, виявлення хромосомної патології серед членів родини); неплідні подружні пари; донори статевих клітин, які звернулися до центрів штучного запліднення.

Виклад основного матеріалу й обгрунтування отриманих результатів дослідження. Проаналізувавши метафазні пластинки та визначивши каріотипи осіб, які були обстежені протягом 20122014 рр., ми розділили всіх досліджуваних на три групи. Групу I склали 416 осіб із нормальним каріотипом (46,XX та 46,XY); групу II - 34 особи, в яких було виявлено варіанти хромосомного поліморфізму; групу III - 109 осіб, у яких виявлено кількісні та структурні хромосомні аномалії (рис. 1). Відмічено зростання кількості обстежень за останній рік (229), відповідно виявлено більше хромосомних патологій (у 39 осіб) та поліморфізмів хромосом (у 20 осіб) порівняно $з$ двома попередніми роками.

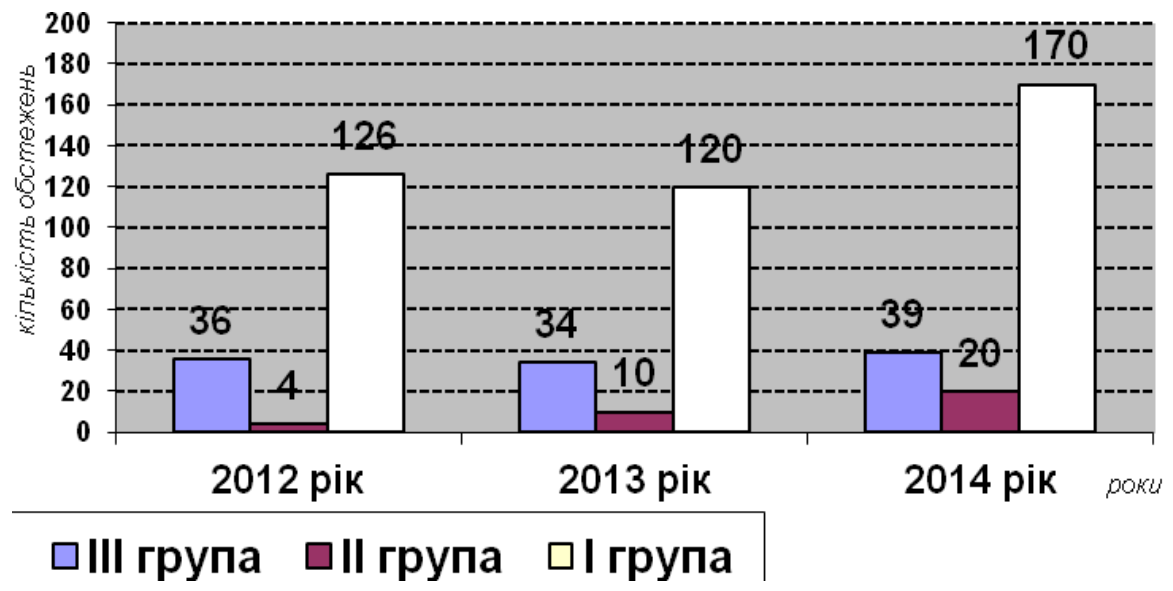

Рис. 1. Динаміка обстежень хромосомної патології за 2012-2014 рр. у Волинській області

Серед хромосомної патології, що становить 19,5 \% (III група, 109 осіб, рис. 1), виявлено анеуплоїдії аутосом (75 \%, 72 випадки), основна частина 3 них представлена трисомією за 21-ю парою хромосом (74 випадки), що клінічно описується як синдром Дауна, з них: регулярні форми - 72 (рис. 2А), мозаїчні - 1, транслокаційні - 1 (рис. 2Б).

Крім класичних форм цієї патології, траплялися поєднані варіанти з іншими аномаліями хромосом, що відображає вплив на фенотипові особливості пацієнта та ускладнює діагностування: $47, \mathrm{XX},+21,21 \mathrm{ps}+; 47, \mathrm{XX},+21,9 \mathrm{ph}$ (рис. 3); 47,XY,+21,9qh-. Трисомія 21 трапляється найчастіше і $\epsilon$ найбільш вивченою хромосомною патологією людини. Частота синдрому Дауна серед новонароджених становить 1:700-1:800.

Найважливішими характеристиками синдрому є такі: це чітко окреслений стан хворого. Незважаючи на значну мінливість окремих ознак, у досвідченого клініциста діагноз рідко викликає сумнів; частота синдрому збільшується з віком матері; у більшості випадків у сім'ї реєструється тільки один хворий, дуже рідко спостерігаються повторні випадки; чоловіки із синдромом Дауна безплідні, однак описані випадки, коли у жінок із цим синдромом були діти; тривалість життя хворих скорочена; ступінь вираженості окремих фенотипових характеристик синдрому мінлива. Наприклад, вроджена вада серця спостерігається у деяких хворих, але не у всіх. Така висока мінливість фенотипових проявів характерна для всіх хромосомних синдромів людини; у 20 разів підвищений ризик смерті від гострого лейкозу. Причини цього невідомі [5]. Хоча дослідження цієї патології тривають, усі чинники, що викликають аномалію, ще досі не вивчені. 


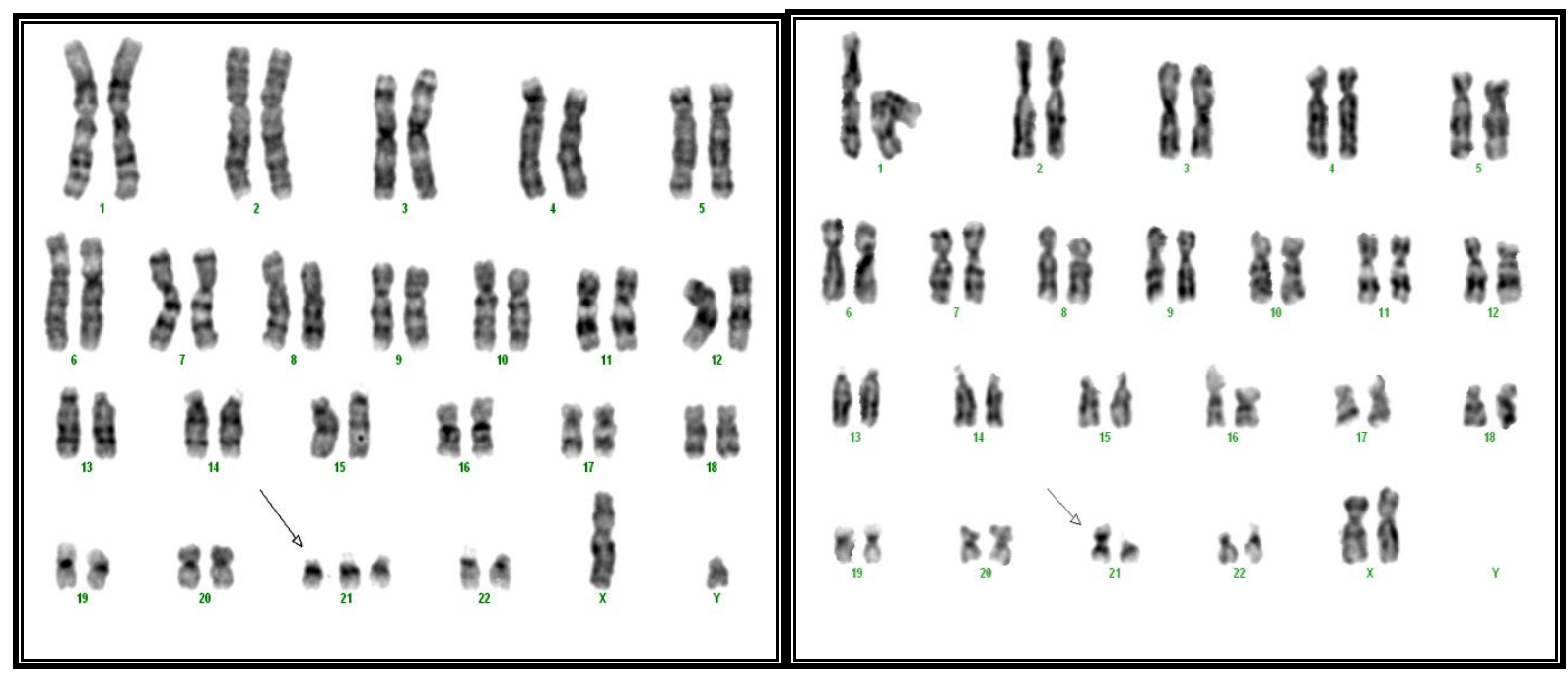

A

Б

Pис. 2. А - каріотип трисомії за 21-ю парою хромосом, або синдрому Дауна $(47, X Y,+21)$; Б - каріотип із транслокаційною формою синдрому Дауна $(46, \mathrm{XX}, \operatorname{der}(21 ; 21)(q 10 ; q 10),+21)$

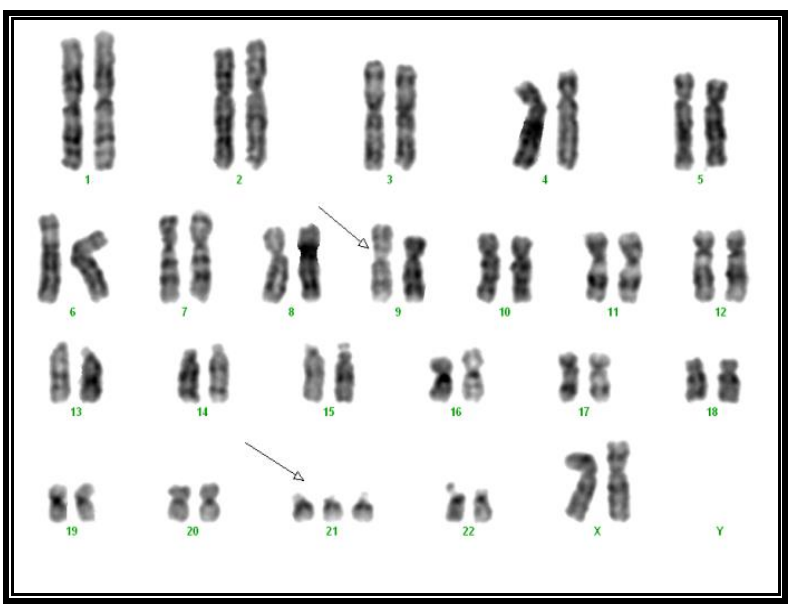

Рис. 3. Каріотип синдрому Дауна та поліморфізму 9-ї хромосоми $(47, \mathrm{XX},+21,9$ ph) (посднана форма)

Регулярну форму синдрому Едвардса виявлено у шести осіб (рис. 4), мозаїчну - в однієї особи. Частота синдрому Едвардса становить 1:5000 - 1:7000 новонароджених. Найбільш значними в діагностиці цієї хвороби є зміни мозкового черепа та лиця, опорно-рухового апарату, вади розвитку серцево-судинної системи. Діти з цим синдромом помирають у ранньому віці (90\% - до 1 року) від ускладнень, обумовлених вродженими вадами розвитку (асфіксія, пневмонія, кишкова непрохідність, серцево-судинна недостатність) [2]. Крім того, в однієї дівчинки було виявлено два клони клітин (рис. 5А та 5Б), в одному з яких є дві маркерні хромосоми (невідомого походження), другий клон із нормальним каріотипом (mos48,XX,+mar1,+mar2[10]/46, XX [30]).

Серед хромосомних хвороб трапляються синдроми, пов'язані з аномаліями статевих хромосом. Iз 17 пацієнтів з такими порушеннями в трьох випадках було діагностовано синдром ШеришевськогоТернера (регулярних форм - дві, каріотип 45,X; мозаїчних - одна, каріотип mos45,X[11]/46,XX[20]), у 10 випадках - синдром Клайнфельтера (всі регулярні форми, каріотип 47,XXY) (рис. 6), один випадок - синдром 46,XY у дівчини, ще один випадок - синдром 46,XX у хлопчика, а також один випадок поєднаної із синдромом Едвардса патології (каріотип 48,XXY,+18) та один випадок дисомії за Y-хромосомою $(47, \mathrm{XYY})$. 


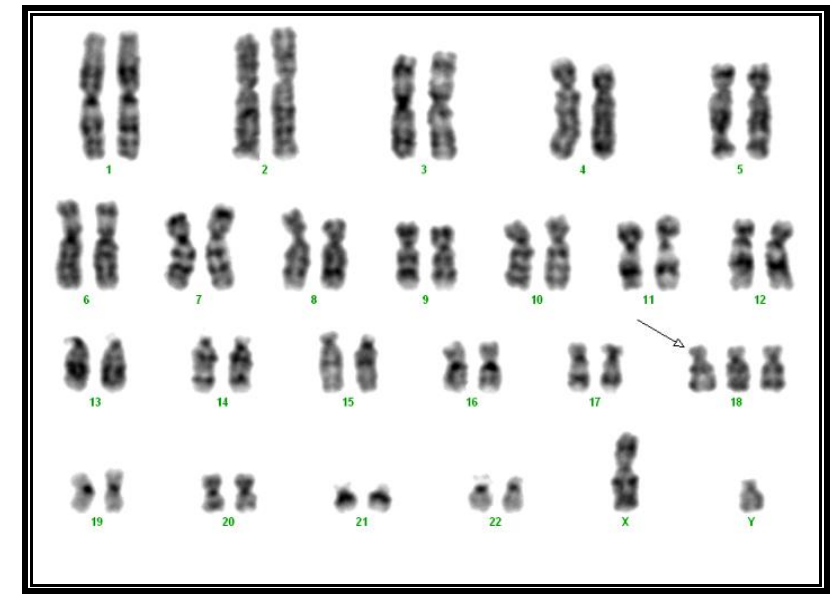

Puc. 4. Каріотип синдрому Едвардса (трисомія за 18-ю парою хромосом) у хлопчика $(47, \mathrm{XY},+18)$

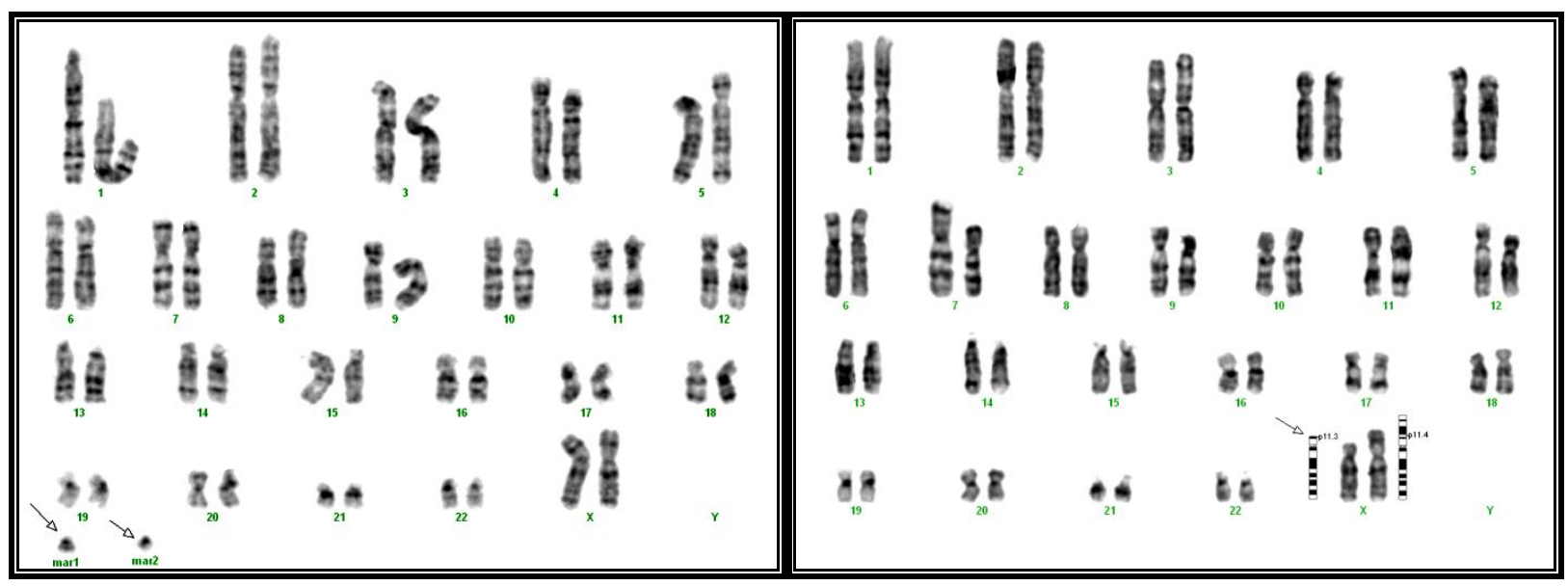

Рис. 5. А - каріотип дівчинки mos48,XX,+mar1,+mar2[10]/46,XX[30] : один клон клітин містить дві різні маркерні хромосоми (10 клітин), другий клон - нормальний набір хромосом (30 клітин); Б - каріотип дівчини з делецією короткого плеча хромосоми Х (моносомія за коротким плечем хромосоми $X), 46, X, \operatorname{del}(X)(: p 11.3->q t e r)$

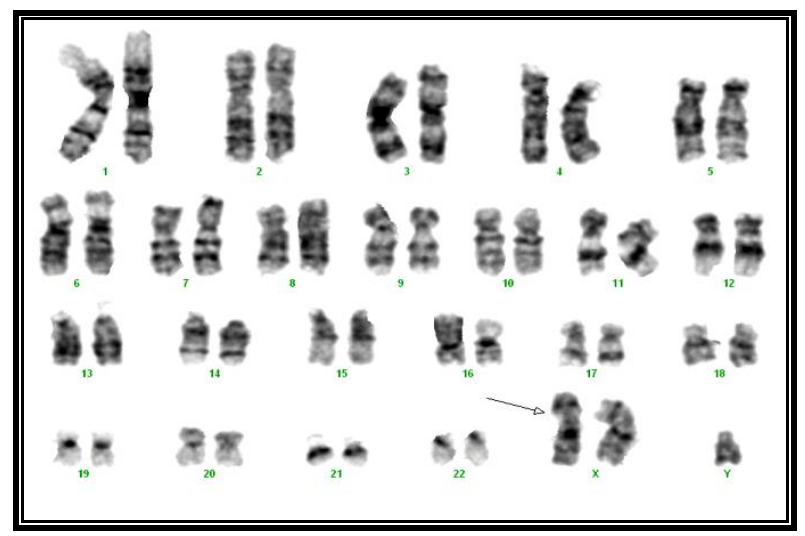

Рис. 6. Каріотип синдрому Клайнфельтера (дисомія за Х-хромосомою у чоловіка) (47, ХХУ)

Поєднана патологія заслуговує особливої уваги, оскільки в кожному конкретному випадку спостерігаються фенотипові прояви, обумовлені комбінацією різних хромосомних аномалій, що значно ускладнює встановлення діагнозу. Частота синдрому Клайнфельтера серед новонароджених хлопчиків становить 1:1000. Наявність Ү-хромосоми визначає формування чоловічої статі. До періоду статевого 
дозрівання хлопчики розвиваються майже нормально, відмічаються лише невеликі відставання в психічному розвитку. Генетичний дисбаланс у зв'язку з додатковою $\mathrm{X}$-хромосомою проявляється клінічно в період статевого дозрівання у вигляді недорозвинутих сім'яників і вторинних чоловічих статевих ознак. У хворих спостерігається високий зріст, жіночий тип тілобудови, гінекомастія, слабке оволосіння лиця, пахвових впадин і лобка, яєчка зменшені. Хворі безплідні (азооспермія, олігоспермія) [2]. Частота синдрому Шеришевського-Тернера (моносомії за Х-хромосомою) серед новонароджених дівчаток становить 1:2000 - 1:5000. Ця хвороба характеризується значною цитогенетичною та клінічною варіабельністю, що пояснюється як істинною моносомією (регулярна форма), так і мозаїцизмом. У каріотипі приблизно 60 \% хворих міститься тільки одна хромосома Х, у решти випадків спостерігається різноманітний мозаїцизм та більш рідкісні варіанти делецій, ізохромосом, кільцевих хромосом. Основні клінічні ознаки синдрому: гіпогонадизм, недорозвиток статевих органів та вторинних статевих ознак, вроджені вади розвитку, низький зріст. Лікування хворих із синдромом Шеришевського-Тернера комплексне: 1) реконструктивна хірургія (вроджені вади внутрішніх органів); 2) пластична хірургія (видалення крилоподібних складок і т. д.); 3) гормональне (естрогени, гормон росту); 4) психотерапевтичне [6]. Синдром дисомії за Ү-хромосомою трапляється з частотою 1:1000 у новонароджених хлопчиків. Більшість чоловіків із таким набором хромосом не відрізняються від нормальних осіб за фізичним та розумовим розвитком, однак мають зріст дещо вищий за середній. Суттєвих відхилень у статевому, гормональному статусі, у плодючості в більшості XYY-індивідів немає. Можливі деякі особливості поведінки таких осіб: за відповідних умов вони схильні до агресивних і навіть кримінальних вчинків [2].

Спектр структурних хромосомних аномалій досить різноманітний. Усього виявлено вісім перебудов, а саме: транслокацій - два випадки: 46,XX,t(5;10)(q21;q21); 45,XX,der(13;14)(q10;q10); делецій п'ять випадків: 46,XX,del(4)(pter->p14:) - синдром Вольфа-Гіршхорна; 46,XX, del(4)(:q31.3->qter) та 46,X,del(X)(pter->p11.3:) (рис. 5Б); 46,XX,del13(pter->p12:); 46,XX,del(6)(pter->q12); додаткового матеріалу невідомого походження - один випадок: 46,XX, add(8)(?::p23->qter).

Структурні перебудови викликають відхилення в розвитку і характерні фенотипові особливості, тому належать до групи хромосомних хвороб. Їх клінічна картина не ідентична фенотиповим змінам повних анеуплоїдій, кожна 3 цих хромосомних перебудов є самостійною нозологічною формою. Структурні перебудови виникають здебільшого як результат неточного кросинговеру хромосом 3 інверсіями або транслокаціями. Лише в невеликої кількості випадків можливе первинне виникнення делеції в гаметі або клітині на ранніх стадіях дроблення [8].

У ході цитогенетичного обстеження у II групи осіб виявлено варіанти хромосомного поліморфізму (індивідуальна мінливість хромосом) (34 випадки, або $6 \%$, рис. 1), що проявляється у варіабельності розміру, розміщенні гетерохроматинових блоків у навколоцентромерних ділянках хромосом 1, 9, 16; розміру гетерохроматинового блоку в довгому плечі хромосоми Ү (рис. 7А); варіабельності розміру та кількості супутників (рис. 7Б), довжини супутникової нитки та навколоядерцевого гетерохроматину коротких плечей акроцентричних хромосом 13-15 та 21, 22. Для виявлення поліморфних варіантів застосовували CBG-метод пофарбування препаратів хромосом. Існує думка про те, що екстремальні варіанти гетерохроматинових ділянок (ГД) можуть безпосередньо впливати на функціонування генів, активних в ембріогенезі. Припущення того, що ембріоспецифічні гени можуть перебувати в ГД хромосом і бути неактивними в постнатальному періоді, неодноразово висловлювали різні групи дослідників [11].

Визначено групи ризиків, у яких збільшення або зменшення ГД спостерігалось частіше. Це насамперед подружні пари 3 порушенням репродуктивної функції, а також діти із затримкою психомоторного розвитку й вродженими вадами розвитку органів. Варіанти $1 \mathrm{qh}+\mathrm{i} 9 \mathrm{qh}+$ (п'ять випадків) частіше від інших екстремальних варіантів супроводжують спонтанні аборти і народження дітей із вадами розвитку. $€$ вказівки на те, що надмірне нагромадження гетерохроматину Ү хромосомою має негативні наслідки. При цьому страждають дві найбільш чуттєві ланки в онтогенезі людини - ембріональний розвиток і становлення вищих форм нервової діяльності, що пов'язані із психікою і соціальною поведінкою людини. Найбільш переконливо доведений вплив довгої хромосоми Y батька на частоту спонтанних абортів [3; 7]. Щодо інверсій ГР хромосом 1,9 , 16, то вони розглядаються як варіанти нормального поліморфізму та згідно з Міжнародною номенклатурою 


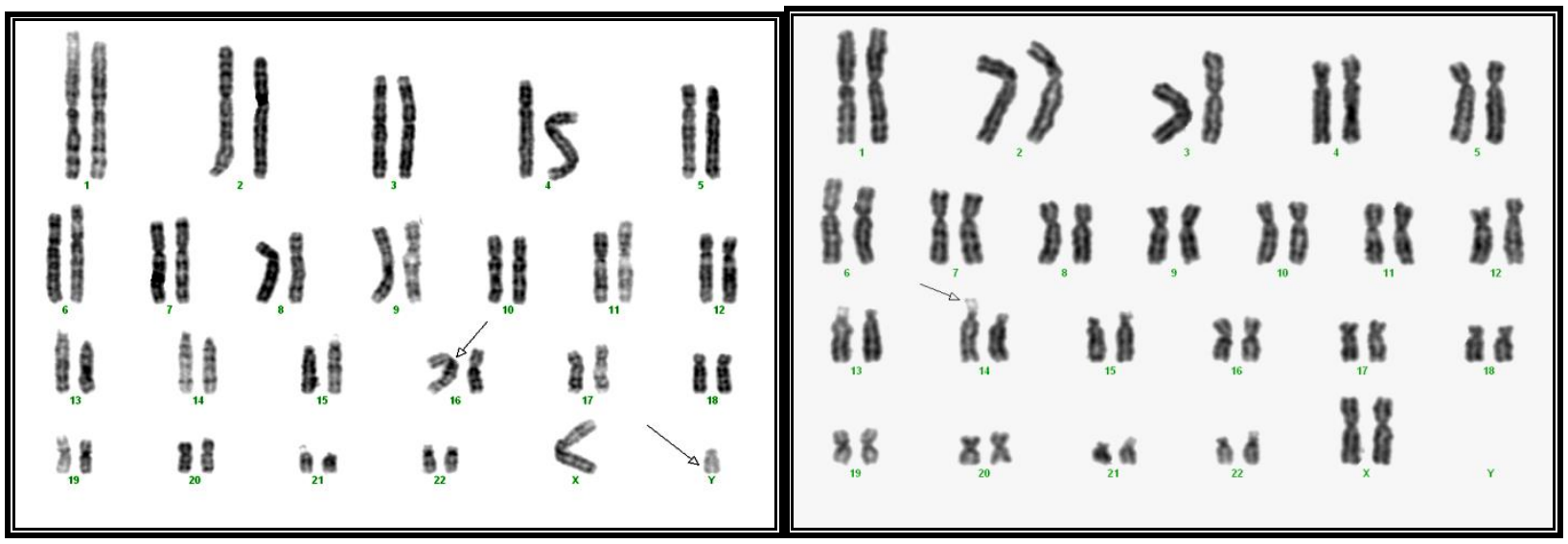

Рис. 7. А - каріотип з поліморфізмами 16-ї хромосоми (збільшений гетерохроматин у довгому плечі) та Y-хромосоми (зменшений гетерохроматин у довгому плечі) (46,XYqh-,16qh+) та Б - каріотип жінки із супутниковим поліморфізмом (подвійні супутники на короткому плечі хромосоми 14) $(46, X X, 14$ pss)

хромосом [12] позначаються як $1 \mathrm{ph}, 9 \mathrm{ph}, 16 \mathrm{ph}$. Ми виявили дев'ять випадків 9ph, що може впливати на нерозходження хромосом, а також збільшення ймовірності спонтанного переривання вагітності та народження дітей із множинними вадами розвитку [13]. Актуальна також проблема виявленого супутникового поліморфізму (11 випадків). Акроцентричні хромосоми містять супутники, короткі плечі хромосом 13, 14, 15, 21, 22 виявляють високу міжхромосомну варіабельність. У деяких випадках спостерігаються подвійні (тандемні) супутники (рис. 10), збільшені розміри супутникових ниток, переважно збільшені розміри супутників. Перед дослідниками проблеми поліморфізму ГД стоїть низка важливих завдань, серед яких слід виділити одне, найбільш важливе для медичних генетиків, - з'ясування тісї межі в розмірах, структурі та властивостях ГД окремих хромосом, яка обумовлює перехід від норми до патології.

Висновки та перспективи подальшого дослідження. Використання класичного методу та сучасних технологій дало змогу виявити у 109 осіб хромосомні аномалії, у 34 - хромосомний поліморфізм для розробки адекватної терапії, індивідуальної тактики поведінки хворого і сім'ї. Останній рік характеризується збільшеною кількістю обстежуваних, відповідно кількість виявлених хромосомних патологій та поліморфізмів більша порівняно з попередніми роками. Ряд патологічних станів, таких як поєднана патологія, випадки маркерних хромосом, структурних перебудов, мозаїчних клонів, хромосомного поліморфізму та інші потребують у подальшому застосування сучасних молекулярно-цитогенетичних методів діагностики (Fish-метод, PCR та інші) для того, щоб проаналізувати набагато більшу кількість клітин на стадії метафази та інтерфази, виявити низькорівневі мозаїчні форми каріотипів, складні структурні мікроаномалії та перебудови. У перспективі використання цитогенетичних методів діагностики хромосомних патологій (і класичних, і сучасних) дасть змогу виявляти дуже рідкісні, навіть неописані випадки хромосомних аномалій.

\section{Джерела та література}

1. Баранов В. С. Цитогенетика эмбрионального развития человека : научно-практические аспекты / В. С. Баранов, Т. В. Кузнецова. - СПб. : Изд-во Н-Л, 2006. - 640 с.: 141 ил.

2. Бочков Н. П. Клиническая генетика : учебник. - 2-е изд., перераб. и доп. / Н. П. Бочков. - М. : ГЕОТАР-МЕД, 2002. - 448 с.: ил.

3. Ворсанова С. Г. Хромосомные аномалии и синдромы при нервно-психических нарушениях / С. Г. Ворсанова, Ю. Б. Юров, Е. Я. Гречанина. - Харьков : [б. и.], 1998. - С. 13-27.

4. Кулешов Н. П. Клиническая цитогенетика в Российской Федерации / Н. П. Кулешов // Современные методы диагностики наследственных болезней : материалы практ. конф. / Н. П. Кулешов. - М., 2001. C. 30-37.

5. Медична біологія : підруч. для студ. вищ. мед. навч. закл. III-IV рівнів акредитації / В. П. Пішак, Ю. І. Бажора, Ш. Б. Брагін [та ін.] ; за ред. В. П. Пішака, Ю. І. Бажори. - Вінниця : Нова книга, 2009. - 607 с.

6. Медична генетика : підручник / за ред. О. Я. Гречаніної, Р. В. Богатирьової, О. П. Волосовця. - К. : Медицина, 2007. -536 с.

7. Прокофьева-Бельговская А. А. Гетерохроматические районы хромосом / А. А. Прокофьева-Бельговская. - М., 1986. - С. 51-56, 213-235, 320-324. 
8. Путинцева Г. Й. Медична генетика : підручник / Г. Й. Путинцева. - К. : Медицина, 2008. - 392 с.

9. Стандарти аналізу препаратів хромосом людини : метод. рек. / уклад. Т. Е. Зерова-Любимова, Н. Г. Горовенко. - К. : [б. в.], 2003. - 52 с.

10. Цитогенетичні методи дослідження хромосом людини : метод. рек. / уклад. Т. Е. Зерова-Любимова, Н. Г. Горовенко. - К. : [б. в.], 2003. - 24 с.

11. Phillips R. B. Intheritance of Q- and C-band polymorphisms / R. B. Phillips // Can. J. Genet. Cytol. - 1997. Vol. 19, № 3. - P. 405-413.

12. Shaffer L. G. ISCN (2005): An International system for human cytogenetic nomenclature / L. G. Shaffer, N. Tommerup, S. Karger. - Basel, 2005. - 130 p.

13. Yamada K. Population studies of inv(9) chromosomes in 4,300 Japanese: incidence, sex difference and clinical significance / K. Yamada // Jpn. J. Hum. Genet. - 1992. - Vol. 37, № 4. - P. 293-301.

Рудник Наталия, Шевчук Татьяна, Поручинська Татьяна. Роль цитогенетической диагностики при выявлении хромосомной патологии и полиморфизмов хромосом в постнатальном периоде развития в Волынской области. Подтверждена важность и необходимость классического цитогенетического метода для диагностики хромосомной патологии, медико-генетического консультирования и прогнозирования потомства в Волынской области. Для проведения цитогенетического анализа использовали метод культивирования лимфоцитов периферической крови человека в постнатальном периоде развития, приготовления препаратов метафазных хромосом человека, определение кариотипа, анализ метафазных пластинок хромосом и выявления хромосомных аномалий и полиморфизмов хромосом. Количество обследуемых за 2012-2014 гг. в Волынской области составило 559 человек женского и мужского пола. В I группе лиц определен нормальный кариотип; во II группе - полиморфизмы хромосом 1, 9, 16, 13-15, 21, 22, Y; в III группе виявлены хромосомные аномалии и подтверждены диагнозы синдромов Дауна, Клайнфельтера, Шеришевского-Тернера, Эдвардса, Вольфа-Гиршхорна, дисомии по Ү-хромосоме, синдрома ХХ у мальчика, синдрома XY у девочки и др.

Ключевые слова: классический цитогенетический метод, хромосомные аномалии, кариотип, метафазные пластинки, синдром, полиморфизм хромосом.

Rudnik Natalia, Shevchuk Tatiana, Poruchinska Tatiana. The Role of Cytogenetic Diagnosis in Villanie Chromosomal Abnormalities and Polymorphisms of Chromosomes in the Postnatal Period of Development in Volyn Region. Confirmed the importance and necessity of classical cytogenetic method for the diagnosis of chromosomal abnormalities, genetic counseling and prediction of offspring in the Volyn region. To conduct cytogenetic analysis used the method of cultivation of peripheral blood lymphocytes of human rights in the postnatal period of development, to prepare preparations of metaphase human chromosomes, karyotype was determined by analyzing metaphase plate of chromosomes, and showed chromosomal abnormalities and polymorphisms of chromosomes. The number surveyed for the 2012-2014 years in Volyn region, which was beaten aimed at examination amounted to 559 people, male and female. In I group surveyed opredelen normal karyotype; in the II group - chromosome polymorphisms 1, 9, 16, 13 - 15, 21, 22, Y; in the III group of viaplana chromosomal anomalies and confirmed diagnoses of Down syndrome, Klinefelter, Shereshevskii-Turner, Edwards, wolf-Hirschorn, disobey Y-chromosome, the syndrome of the twentieth century boy syndrome XY the girl and other.

Key words: classical cytogenetic method, chromosomal abnormalities, karyotype, metaphase plate, syndrome, polymorphism of chromosomes.

Стаття надійшла до редколегії 08.03.2015 p.

УДК612.35:612.14:612.15

\section{Людмила Слободяник Петро Янчук Свдокія Решетнік}

\section{Вплив сірководню на кровообіг у печінці щурів при портальній гіпертензії}

У дослідах на лабораторних щурах-самцях показано, що при натрій-йодній моделі портальної гіпертензії (ПГ) спостерігається підвищення артеріального тиску на 37 \% (р < 0,01), тиску у ворітній веніна 75,5 \% (p < 0,01) та

(C) Слободяник Л., Янчук П., Решетнік С., 2015 